\title{
EARTHWORM ACTIVITY IN FOREST AND SAVANNA SOILS NEAR BOA VISTA, RORAIMA, BRAZIL.
}

\author{
Rafael Torquemada GUERRA ${ }^{1}$
}

\begin{abstract}
RESUMO - De maio a dezembro de 1992 a atividade das minhocas foi estudada como parte do Programa ECOFIT na regiāo de Surrão a $30 \mathrm{~km}$ de Boa Vista. Verificou-se a duração e quantificou-se essa atividade através da produção de excrementos na superfície do solo. Estabelecemos três transectos: um com $100 \mathrm{~m}$ de comprimento na savana, outro com $40 \mathrm{~m}$ na área de transição e um outro com $100 \mathrm{~m}$ na floresta. Os animais foram coletados mensalmente ao longo dos transectos de acordo com o método proposto pelo TSBF e os excrementos foram coletados nos quadrados previamente colocados nos transectos. Duas espécies de minhocas foram encontradas nas três áreas: Pontoscolex roraimensis e Pontoscolex corethrurus. A primeira espécie depositava seus excrementos na superfície do solo. A estação chuvosa que normalmente ocorre de abril a agosto determinou a duração da atividade das duas espécies. Entretanto, 1992 foi atípico e a estação chuvosa só começou em maio. $P$. roraimensis produziu excrementos nas três áreas de maio a agosto entrando então em estivação. Na savana $P$. corethrurus entrou em estivação na mesma época mas permaneceu em atividade até novembro nas duas outras áreas. $P$. roraimensis foi encontrada a até $50 \mathrm{~m}$ da borda da floresta sempre associada à presença de Curatella americana e Byrsonima sp, dois arbustos típicos da savana.
\end{abstract}

Palavras chave: minhocas, atividade de minhocas, Amazônia.

Estudo da atividade das minhocas em solo de floresta e de savana próximo de Boa Vista, Roraima, Brazil.

ABSTRACT - From May to December, 1992 we studied the earthworm activity, as part of the ECOFIT Program at Surrão ( $30 \mathrm{~km}$ from Boa Vista), verifying the duration of the activity and quantifying it through the casts deposited on the soil surface. Three transects were stablished: a $100 \mathrm{~m}$ long in the savanna, a $40 \mathrm{~m}$ in the transitional area and $100 \mathrm{~m}$ long in the forest. Specimens were collected monthly along the transects according to the method proposed by TSBF and the casts were collected from the squares previously placed on the transects. Two earthworm species were found in the three areas: Pontoscolex roraimensis and Pontoscolex corethrurus. The first species depositing its casts on the soil surface. Rainy season wich usually occurs from April to August, determined the duration of activity for the two species (however, 1992 was atypical in that rainy season, only started in May). $P$. roraimensis produced casts in the three areas from May to August followed by aestivation. In the savanna, $P$. corethrurus started aestivation in the same period as $P$. roraimensis but remained active until November in the two other areas. $P$. roraimensis was found up $50 \mathrm{~m}$ from the forest border, being associated to the presence of Curatella americana and Byrsonima sp, two typical savanna bushes.

Key-words: earthworms, earthworm activity, Amazonia.

INTRODUCTION

The State of Roraima is mostly covered by a vegetation mosaic of dense tropical rainforest and savanna. A vast contact area between these vegetation types (tran- sitional area) occurs in the vicinity of the State capital, Boa Vista. Some researchers as AB'SABER $(1966 ; 1973)$ have shown two interesting aspects of these vegetal formations. The first indicated that the forest seemed to advance onto the savanna, the

Dpto. Sistemática e Ecologia, CCEN Universidade Federal da Paraíba 58059-900 João Pessoa, PB, Brasil. 
latter representing a relict of a preterit period of dry climate. The other presents evidence that the savannas of Roraima are similar in their floristic composition to others found in other Amazonian localities and Central Brazil.

As a complement to the pedological studies of the ECOFIT Program, wich investigates the first aspect through botanical, palinological and pedological studies, we propose to investigate the role of earthworms in the forest-savanna transitional soils, beginning by their activity study.

\section{METHODOLOGY}

A transect with $240 \mathrm{~m}$ in length was stablished in the study area( Surrão, near Boa Vista), of which $100 \mathrm{~m}$ were located in the savanna, $40 \mathrm{~m}$ in the transitional area, and the remaining $100 \mathrm{~m}$ in the forest. To quantify the activity of the earthworms we followed the method suggested by GUERRA (1988), using 50x50 cm squares in the soil surface, eight in the savanna, four in the transitional area and eight in the forest. The casts produced into the squares were collected fortnightly and had their dry weigth determined. The animals were quantified by the TSBF method (ANDERSON \& INGRAM, 1989), used monthly with the same number of squares as for the casts. The earthworms were separated by species and state of development, counted and weighted.

\section{RESULTS AND DISCUSSION}

The study was realized from May to December, 1992. The choosen area is caracterized by a tropical climate with a rainy season (from April through August) and a dry season (September through March), with mean monthly temperature above $15^{\circ} \mathrm{C}$. The relief is flat with altitudes between 100 and $130 \mathrm{~m}$ and the soil is latosol yellow type (IBGE, 1991). The savanna vegetation is dominated by Curatella americana and Byrsonima sp, both shrubby, and by the grasses Andropogon angustatus and Trachypogon plumosus. The year of 1992 was atypical because the torrential rains started in May instead of April. Table 1 shows the rainfall and soil moisture data in the study period.

The two earthworms species found along the transect, Pontoscolex roraimensis a $\mathrm{n}$ d Pontoscolex corethrurus (Glossoscolecidae), started their activity after the onset of the rains. The relationship between earthworm activity and rainfall had been observed for other tropical areas by GATES (1961), WATANABE \& RUAYSOONGNERN (1984), GUERRA (1988), FRAGOSO \& LAVELLE (1987) and GUERRA \& SILVA (in press). Table 2 shows the monthly earthworm density and biomass during the study period. $P$. corethrurus dominated in density, while $P$. roraimensis dominated in biomass. According to RIGHI (1990), P. corethrurus is the most common earthworm species in Brazil, wich conforms to our observed density data. GUERRA \& SILVA (in press) working in three areas in Northeast Brazil (Mata Atlântica) verified that $P$. corethrurus occured in all areas and dominated in density in two areas and in biomass in all. The most part of $P$. roraimensis individuals occured in the transition area, 
Table 1. Rainfall (mm) and soil moisture in forest and savanna during the study period.

\begin{tabular}{lccc}
\hline \multicolumn{1}{c}{$\begin{array}{c}\text { Site } \\
\text { Month }\end{array}$} & Moisture & Forest & Savanna \\
Jan/92 & - & 0.0 & Moisture \\
Feb & - & 74,6 & - \\
Mar & - & 24,6 & - \\
Apr & - & 96,8 & - \\
May & 5,4 & 118,2 & - \\
Jun & 10,1 & 227,5 & 10,5 \\
Jul & 9.0 & 295,4 & 18,1 \\
Aug & 4,5 & 155,4 & 15,2 \\
Sep & 1,8 & 10,6 & 11,9 \\
Oct & 1,6 & 4.0 & 5,8 \\
Nov & 1,7 & 21,8 & 3,4 \\
Dec & - & 3.0 & 1,8 \\
\hline
\end{tabular}

Table 2. Density(D) in number of individuals $/ \mathrm{m}^{2}$, biomass(B) in $\mathrm{g} / \mathrm{m}^{2}$ of fresh weight and casts(C) production in $\mathrm{g} / \mathrm{m}^{2}$ along the study period.

\begin{tabular}{ccccccccccc}
\hline Site & \multicolumn{3}{c}{ Savanna } & \multicolumn{3}{c}{ Transition } & \multicolumn{5}{c}{ Forest } \\
& D & B & C & D & B & C & D & B & C \\
Month & & & & & & & & & \\
May & 7,9 & 3,7 & 115.0 & 13.0 & 7,5 & 143,1 & 15.0 & 6,2 & 83,1 \\
Jun & 3,5 & 3,3 & 50.0 & 6,5 & 5,5 & 60,9 & 3,9 & 2,4 & 62,1 \\
Jul & 22,5 & 8,8 & 40,7 & 33,4 & 12.0 & 167,1 & 19,3 & 12,6 & 77,2 \\
Aug & 7,1 & 2,7 & 17,9 & 43,3 & 21,1 & 144.0 & 26,8 & 11,8 & 100.0 \\
Sep & - & - & 57,9 & 3,5 & 0,3 & 134,4 & 12,6 & 1,5 & 128,7 \\
Oct & - & - & - & 2,4 & 0,3 & - & 6,7 & 0,9 & - \\
Nov & - & - & - & 12,1 & 2,3 & - & 23,7 & 5,6 & - \\
Dec & - & - & - & - & - & - & - & - & - \\
\hline
\end{tabular}

followed by the forested area, and least in the savanna. In the latter its occurence was restricted to a stretch $50 \mathrm{~m}$ distant from the margin of the forest, associated with the presence of C. americana and Byrsonima sp. Young individuals were observed from July on, in higher numbers than adults in all three areas. $P$. corethrurus presented the same spatial ditribution pattern but young individuals predominated all along the study period.
Both $P$. roraimensis and $P$. corethrurus use aestivation strategy to cope with adverse conditions during the dry season, but apparently, $P$. corethrurus produces a great number of cocoons before entering aestivation. Cocoons were abundant along the study period. The higher biomass and density occured in the transition area and forest (Tab. 2).

Apparently, $P$. roraimensis has narrower tolerance ranges for soil 
moisture than $P$. corethrurus, as had been also observed to Chibui bari (Glossoscolecidae) in a study in Acre, Western Amazonia (GUERRA, in press). In the present study, as soon as the rains were over, all individuals entered in aestivation in depths around $40-50 \mathrm{~cm}$. In the savanna $P$. corethrurus had the same behavior, remaining active in the transition and forest areas through November.

The production of casts on the soil surface, exclusively by $P$. roraimensis, occured from May to September, reaching $562,8 \mathrm{Kg} \cdot \mathrm{ha}^{-1} \cdot \mathrm{yr}^{-1}$ in the savanna, $1.299,1 \mathrm{Kg} \cdot \mathrm{ha}^{-1} \cdot \mathrm{yr}^{-1}$ in the transition and $903,2 \mathrm{Kg} \cdot \mathrm{ha}^{-1} \cdot \mathrm{yr}^{-1}$ in the forest. This production of casts is low when compared with those of other tropical regions, but we must consider the short time span favorable to activity of this species in this region, which lasts five months at most.

Contrarywise to the observation of GUERRA (in press) for the casts of C. bari, which were predominantly claysh, those of $P$. roraimensis were essentially sandy. The earthworm casts were less abundant in the soil surface of the savanna than in the transition area and in the forest, but nevertheless formed the major layer of the superficial strata.

The great quantity of soil circulated by earthworm in the study area possibly contribute in the deposition of a layer of fine sand mixed with clay on the soil surface, specially that of the savanna, forming small islands around the individuals of $C$. americana and Byrsonima sp.
Finally, the role of the earthworm in the differentiation of soils in the forest-savanna transition should be better understood with further studies in pedology and earthworm activity.

\section{ACKNOWLEDGEMENTS}

We thank Drs. Armand Chauvel and Thierry Desjardins from INPA/ ORSTOM; Edileusa S. Silva from MIR(Roraima) and Everaldo G. Silva from UFPB(Paraiba) for technical aid and ORSTOM for financial support.

\section{Literature cited}

AB'SABER, A. N. 1966. O domínio morfoclimático amazônico. Geomorfologia, 1:1-6.

...- 1973. A organização das paisagens inter e subtropicais brasileiras. Geomorfologia, 41:1-39.

ANDERSON, J. M.; INGRAM, J. S. I. 1989. TSBF Methods Handbook. UNESCO, IUBS, 77p.

FRAGOSO, C.; LAVELLE, P. 1987. The earthworm community of a Mexican tropical rainforest (Chajul, Chiapas). In: On Earthworms. (A. M. Bonvicini-Pagliai and P. Omodeo Ed.), Mucchi, Modena, pp. 281295.

GATES, G. E. 1961. Ecology of some earthworms with special reference to seasonal activity. Am. Midl. Nat., 66:61-86.

GUERRA, R. T. 1988. Ecologia dos Oligochaeta da Amazônia. II. Estudo da estivação e da atividade de Chibui bari através da produção de excrementos. Acta Amazonica, 18(1-2):27-34.

GUERRA, R. T. in press. Sobre a comunidade de minhocas (Annelida, Oligochaeta) do campus da Universidade Federal do Acre, Rio Branco(AC), Brasil. Rev. Bras. Biol. 54(4): 593-601. 1994

GUERRA, R. T.; SILVA, E. G. in press. Estudo das comunidades de minhocas (Annelida, Oligochaeta) em alguns ambientes terrestres 
do Estado da Paraíba. Rev. Nord. Biol. 9(2): 209-223.

IBGE. 1991. Geografia do Brasil. Região Norte. Instituto Brasileiro de Geografia e Estatística, Rio de Janeiro, 307p.
RIGHI, G. 1990. Minhocas de Mato Grosso e Rondônia. CNPq, Brasília, 157p.

WATANABE, H.; RUAYSOONGNERN, S. 1984. Cast production by the megascolecid earthworm Pheretima $\mathrm{sp}$ in northeastern Thailand. Pedobiologia, 26:37-44. 